\title{
In vitro modeling to determine mutation specificity of EGFR tyrosine kinase inhibitors against clinically relevant EGFR mutants in non-small-cell lung cancer
}

\author{
Toshiyuki Hirano ${ }^{1, *}$, Hiroyuki Yasuda ${ }^{1}$, Tetsuo Tani ${ }^{1, *}$, Junko Hamamoto ${ }^{1}$, Ayano \\ Oashi $^{1}$, Kota Ishioka ${ }^{1}$, Daisuke Arai ${ }^{1}$, Shigenari Nukaga ${ }^{1}$, Masayoshi Miyawaki ${ }^{1}$, \\ Ichiro Kawada ${ }^{1}$, Katsuhiko Naoki², Daniel B. Costa ${ }^{3}$, Susumu S. Kobayashi ${ }^{3}$, \\ Tomoko Betsuyaku ${ }^{1}$, Kenzo Soejima ${ }^{1}$ \\ ${ }^{1}$ Division of Pulmonary Medicine, Department of Medicine, Keio University, School of Medicine 35 Shinanomachi, Shinjuku-ku, \\ Tokyo, Japan \\ ${ }^{2}$ Keio Cancer Center, Keio University, School of Medicine 35 Shinanomachi, Shinjuku-ku, Tokyo, Japan \\ ${ }^{3}$ Division of Hematology/Oncology, Beth Israel Deaconess Medical Center, Harvard Medical School, Boston, MA, USA \\ *These authors have contributed equally to this work
}

Correspondence to:

Hiroyuki Yasuda, e-mail: hiroyukiyasuda@a8.keio.jp

Kenzo Soejima, e-mail: ksoejima@cpnet.med.keio.ac.jp

Keywords: EGFR mutation, EGFR tyrosine kinase inhibitors, EGFR exon 20 insertion mutations, in vitro modeling, lung cancer Received: August 18, $2015 \quad$ Accepted: October 03, $2015 \quad$ Published: October 15, 2015

\section{ABSTRACT}

EGFR mutated lung cancer accounts for a significant subgroup of non-small-cell lung cancer (NSCLC). Over the last decade, multiple EGFR tyrosine kinase inhibitors (EGFR-TKIs) have been developed to target mutated EGFR. However, there is little information regarding mutation specific potency of EGFR-TKIs against various types of EGFR mutations. The purpose of this study is to establish an in vitro model to determine the "therapeutic window" of EGFR-TKIs against various types of EGFR mutations, including EGFR exon 20 insertion mutations. The potency of $1^{\text {st }}$ (erlotinib), $2^{\text {nd }}$ (afatinib) and $3^{\text {rd }}$ (osimertinib and rociletinib) generation EGFR-TKIs was compared in vitro for human lung cancer cell lines and Ba/F3 cells, which exogenously express mutated or wild type EGFR. An in vitro model of mutation specificity was created by calculating the ratio of IC50 values between mutated and wild type EGFR. The in vitro model identified a wide therapeutic window of afatinib for exon 19 deletions and L858R and of osimertinib and rociletinib for T790M positive mutations. The results obtained with our models matched well with previously reported preclinical and clinical data. Interestingly, for EGFR exon 20 insertion mutations, most of which are known to be resistant to $1^{\text {st }}$ and $2^{\text {nd }}$ generation EGFR-TKIS, osimertinib was potent and presented a wide therapeutic window. To our knowledge, this is the first report that has identified the therapeutic window of osimertinib for EGFR exon 20 insertion mutations. In conclusion, this model will provide a preclinical rationale for proper selection of EGFR-TKIs against clinically-relevant EGFR mutations.

\section{INTRODUCTION}

Lung cancer is the leading cause of cancer related death worldwide [1]. The identification of somatic mutations within the epidermal growth factor receptor $(E G F R)$ kinase domain helped our understanding of the biology of lung cancer harboring EGFR mutations [2-6].
EGFR mutations are expected to activate the EGFR by destabilizing the inactive form of EGFR without ligand stimulation [7-9]. Activated EGFR induces EGFRmediated pro-survival and anti-apoptotic signals through downstream targets such as extracellular-signal-regulated kinase (ERK)/mitogen-activated protein kinase (MAPK) and phosphatidylinositol-3-kinases (PI3K)/protein kinase 
B (AKT) $[10,11]$. Inhibition of the EGFR pathway leads to the down-regulation of pro-survival signals and upregulation of pro-apoptotic molecules [12], by which EGFR tyrosine kinase inhibitors (EGFR-TKIs) exert their dramatic effects in patients with EGFR mutated lung cancer.

EGFR mutations have been identified in approximately $10-30 \%$ of non-small-cell lung cancer (NSCLC) [13, 14]. The most common, "classic" mutations are in-frame deletions around the LREA motif of exon 19 (approximately $45 \%$ of EGFR mutations) and the exon 21 L858R point mutation (approximately $40 \%$ of $E G F R$ mutations). Other relatively rare EGFR mutations include, G719X (3\% of EGFR mutations) and L861Q ( $2 \%$ of $E G F R$ mutations) [10]. Another main group of $E G F R$ mutations include exon 20 insertion mutations $(4-10 \%$ of EGFR mutations) [15, 16].

EGFR tyrosine kinase inhibitors (EGFR-TKIs) have been developed to target mutated EGFR. EGFRTKIs reversibly or irreversibly bind to the ATP binding pocket of EGFR and inhibit the phosphorylation of EGFR, thereby inhibiting the activation of the EGFR signaling pathway. The exon 19 deletions, L858R, G719X, and L861Q mutations are $1^{\text {st }}$ generation EGFR-TKIs, gefitinib and erlotinib, sensitizing mutations. The response rates to gefitinib or erlotinib are around $60-80 \%[14,17]$.

Most EGFR exon 20 insertion mutations are $1^{\text {st }}$ generation EGFR-TKIs resistant mutations $[15,18,19]$. One exception is EGFR A763_Y764insFQEA, which we previously reported as another $1^{\text {st }}$ generation EGFRTKIs sensitizing mutation [20]. For these $1^{\text {st }}$ generation EGFR-TKIs resistant exon 20 insertion mutations, no potent inhibitor has been reported. Therefore, patients with NSCLC harboring EGFR exon 20 insertion mutations present a shorter survival time compared to patients with classic EGFR mutations [21]. The development of EGFR-TKIs, which effectively inhibit EGFR with exon 20 insertions, but not the wild type EGFR, has been anticipated.

The $1^{\text {st }}$ generation reversible EGFR-TKIs, gefitinib and erlotinib, dramatically changed the treatment strategy for patients harboring EGFR mutated lung cancer. The significant benefit of gefitinib or erlotinib for patients with NSCLC harboring EGFR-TKIs sensitizing mutations was repeatedly demonstrated in multiple clinical trials $[22,23]$. However, despite the initial favorable response, lung cancer cells eventually acquire resistance to gefitinib or erlotinib. EGFR T790M mutations account for about 50\% of acquired resistance to gefitinib or erlotinib [24, 25]. To target EGFR mutations, including EGFR T790M mutation, multiple EGFR-TKIs have been developed. These include $2^{\text {nd }}$ generation EGFR-TKIs, afatinib [26] and dacomitinib [27, 28], as well as $3^{\text {rd }}$ generation EGFRTKIs, WZ4002 [29], osimertinib (formerly AZD9291) $[30,31]$ and rociletinib $[32,33]$.
Afatinib, a clinically available $2^{\text {nd }}$ generation EGFR-TKI, is potent against EGFR mutated lung cancer cells in vitro [26] and in vivo [34, 35]. However, for EGFR T790M mutated lung cancer, it failed to overcome EGFR T790M-mediated resistance in patients [36, 37]. Osimertinib and rociletinib are $3^{\text {rd }}$ generation EGFRTKIs, both of which are reported to be effective in lung cancer cells harboring EGFR T790M in preclinical models [30, 32]. Promising results of phase I/II study of osimertinib and rociletinib have recently been published. Osimertinib showed a promising safety and efficacy, the response rate and progression free survival for EGFR T790M positive patients was $61 \%$ and 9.6 months, respectively [38]. Similarly, the response rate of rociletinib for EGFR T790M positive patients was 59\% [39].

Today, we have multiple EGFR-TKI options to treat patients with lung cancer harboring EGFR mutations. However, there is no clear guideline regarding which EGFR-TKIs should be used for which mutation. To solve this problem and provide a model, which clinicians or physician scientists could refer to, we examined and compared the potency of EGFR-TKIs against lung cancer cell lines harboring various types of EGFR mutations. In addition, we created an in vitro model, which allows us to determine the therapeutic window of EGFR-TKIs. This model will provide a preclinical rationale for proper selection of EGFR-TKIs against clinically-relevant EGFR mutations.

\section{RESULTS}

\section{Comparison of the sensitivity/resistance profile of Ba/F3 stable cell lines}

In order to directly compare the sensitivity of multiple EGFR mutations to EGFR-TKIs, we generated $E G F R$ transduced $\mathrm{Ba} / \mathrm{F} 3$ stable cell lines. Wild type and mutated $E G F R$ were exogenously transduced into $\mathrm{Ba} / \mathrm{F} 3$ cells. The sensitivity to EGFR-TKIs was evaluated by MTS assay with or without EGFR-TKIs.

Cell growth of $\mathrm{Ba} / \mathrm{F} 3$ cells harboring classic $E G F R$ mutations, exon 19 deletion (exon 19del) and L858R, was dramatically inhibited by afatinib (Figure 1A). Although less potent than afatinib, erlotinib effectively inhibited the proliferation of $\mathrm{Ba} / \mathrm{F} 3$ cells. The potency of osimertinib was comparable to that of erlotinib, while rociletinib was less potent than erlotinib and osimertinib.

Erlotinib did not inhibit the proliferation of $\mathrm{Ba} / \mathrm{F} 3$ cells harboring EGFR T790M mutations, EGFR exon 19del+T790M, and L858R+T790M, at low concentrations. However, afatinib and $3^{\text {rd }}$ generation EGFR-TKIs, osimertinib and rociletinib, effectively inhibited the proliferation of $\mathrm{Ba} / \mathrm{F} 3$ cells (Figure $1 \mathrm{~B}$ ).

In the clinic, skin rash, interstitial pneumonia, or diarrhea are common or life threatening side 

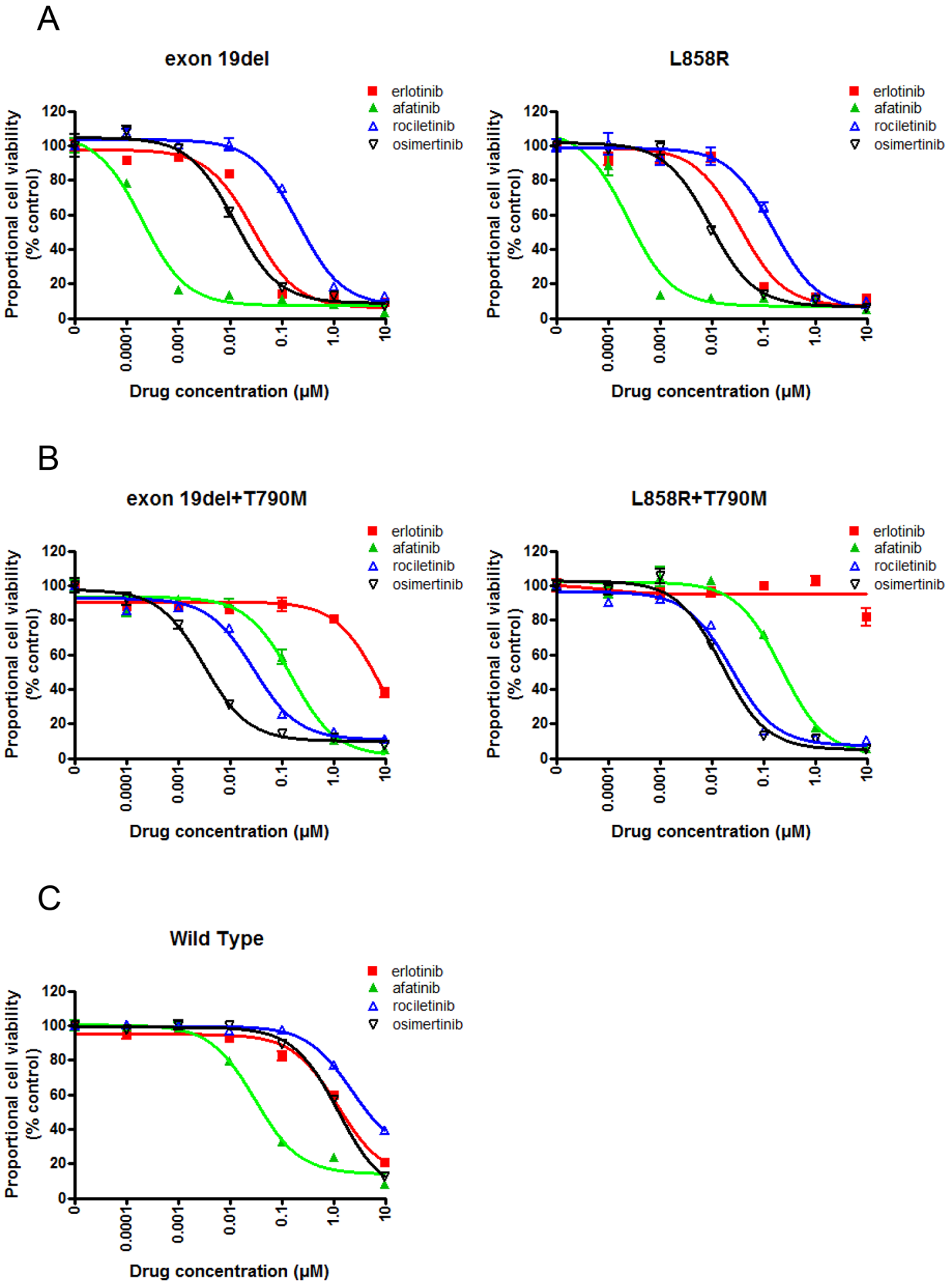

Figure 1: Sensitivity of $\mathrm{Ba} / \mathbf{F} 3$ cells harboring $\boldsymbol{E G F R}$ mutations to EGFR-TKIs. A. MTS assay for Ba/F3 cells harboring EGFR exon 19 deletion and L858R. The proportional cell viability is shown. B. MTS assay for $\mathrm{Ba} / \mathrm{F} 3$ cells harboring EGFR exon 19 deletion+T790M and L858R+T790M. The proportional cell viability is shown. C. MTS assay for Ba/F3 cells harboring wild type EGFR. The proportional cell viability is shown. Erlotinib, afatinib, osimertinib, and rociletinib were used as EGFR-TKIs. Error bars indicate standard deviation.

effect of EGFR-TKIs. These side effects most likely due to the inhibition of the wild type EGFR expressed in the epithelial cells present in the skin, lungs, and gastrointestinal tract by EGFR-TKIs. Hence,
EGFR-TKIs highly selective to mutated EGFR, but not to wild-type EGFR, can efficiently inhibit mutated EGFR in lung cancer cells without affecting the wild type EGFR expressed in epithelial cells. To evaluate 
the effect of EGFR-TKIs on the wild type EGFR, we performed an MTS assay in the presence of EGF and with or without EGFR-TKIs (Figure 1C). Ba/F3 cells were efficiently inhibited by afatinib. The IC50 value of afatinib was $31 \mathrm{nM}$, whereas those of the other three EGFR-TKIs were comparable, indicating that afatinib was the most potent EGFR-TKI against the wild type EGFR.

Immunoblotting was then performed to examine whether the aforementioned effect of EGFR-TKIs on $\mathrm{Ba} / \mathrm{F} 3$ cells was exerted through inhibition of the EGFR signaling pathway (Figure 2).

In $\mathrm{Ba} / \mathrm{F} 3$ cells harboring classic $E G F R$ mutations, exon 19 deletions and L858R, afatinib dramatically inhibited the phosphorylation of EGFR, AKT, and ERK. Erlotinib and osimertinib comparably inhibited the phosphorylation of EGFR, AKT, and ERK. Erlotinib did not inhibit the phosphorylation of EGFR, AKT, and ERK in Ba/F3 cells harboring EGFR T790M mutations, exon 19del+T790M, and L858R+T790M. However, afatinib and $3^{\text {rd }}$ generation EGFR-TKIs, osimertinib and rociletinib, effectively inhibited the phosphorylation of EGFR, AKT, and ERK. These data indicate that the sensitivity of $\mathrm{Ba} / \mathrm{F} 3$ cells to EGFR-TKIs was mediated through inhibition of the EGFR and downstream signals.

\section{Establishment of an in vitro model to determine the therapeutic window of EGFR-TKIs}

The IC50 values of all EGFR-TKIs examined in this study are summarized in Figure 3A. Afatinib is reported to be ineffective against lung cancer harboring EGFR T790M positive mutations, because concentrations at which afatinib inhibits lung cancer cells harboring EGFR T790M are not achievable in humans due to dose limiting toxicities such as skin rash and diarrhea, indicating a narrow therapeutic window of afatinib for $E G F R$ T790M [40].

To provide an estimation of the therapeutic window of EGFR-TKIs, we created an in vitro model by calculating the ratio of IC50 values of the wild type $E G F R$ and mutated $E G F R$, referred to as the selectivity index (SI) (Figure 3B). In this model, the selectivity of each EGFR-TKI is high if the SI value is low. For $\mathrm{Ba} / \mathrm{F} 3$ cells harboring classic EGFR mutations, exon 19 deletions and L858R, afatinib showed the lowest SI values among EGFR-TKIs studied in this study,
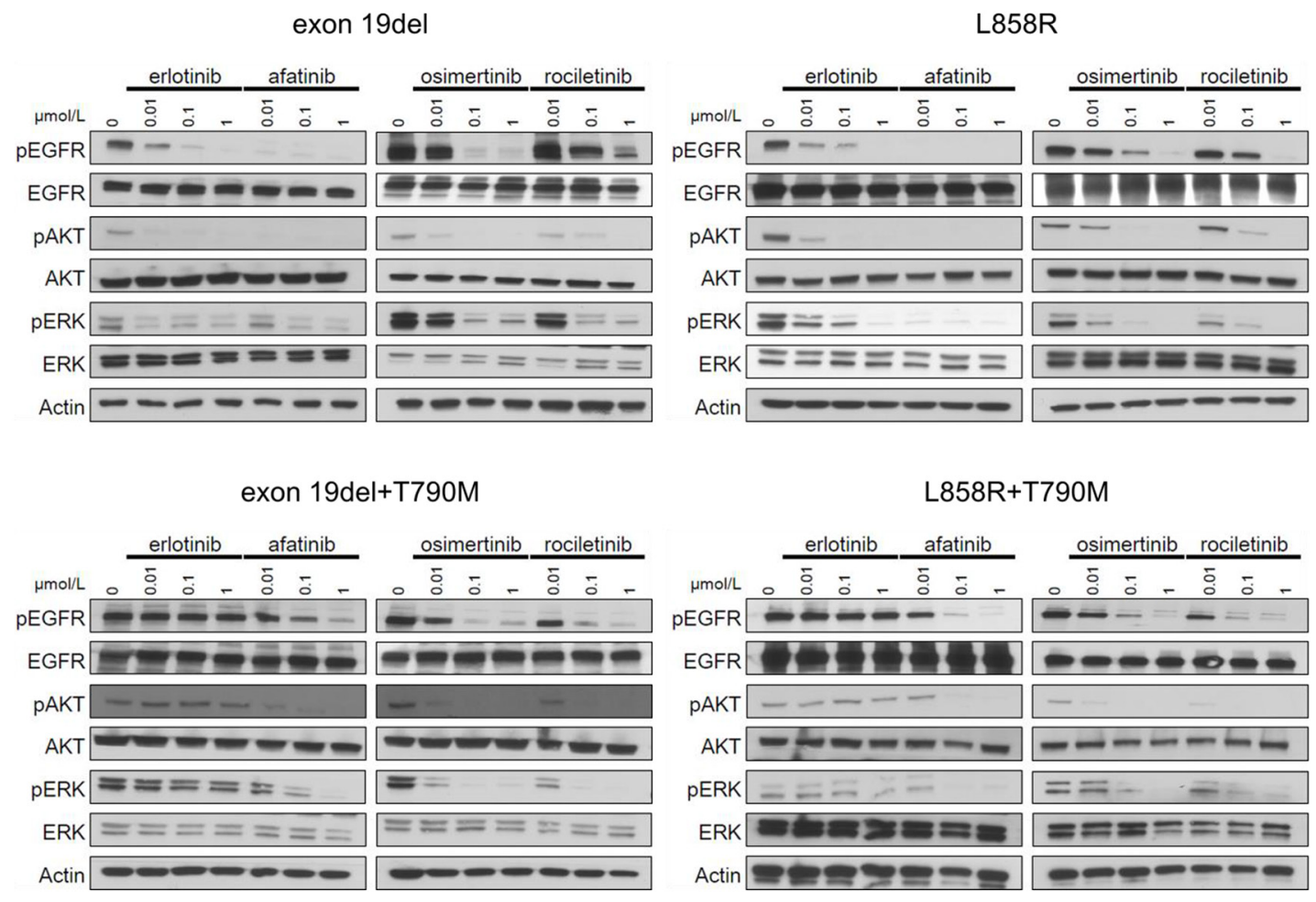

Figure 2: Inhibition of the phosphorylation of EGFR and downstream proteins by EGFR-TKIs in BaF3 cells harboring $\boldsymbol{E} \boldsymbol{G F R}$ mutations. The results of immunoblotting for Ba/F3 cells with $E G F R$ exon 19 deletion, L858R, exon 19 deletion+T790M, and L858R+T790M are shown. The cells were treated with the indicated concentrations of EGFR-TKIs for 4 h. Erlotinib, afatinib, osimertinib, and rociletinib were used as EGFR-TKIs. pEGFR, pAKT, and pERK indicate the phosphorylated form of EGFR, AKT, and ERK, respectively. Actin was used as a loading control. 


\section{A}

\section{$\mathrm{IC}_{50}$ value $(\mathrm{nM})$}

\begin{tabular}{|c|c|c|c|c|c|}
\hline & exon 19del & L858R & $\begin{array}{c}\text { exon 19del } \\
+ \text { T790M }\end{array}$ & $\begin{array}{c}\text { L858R } \\
+ \text { T790M }\end{array}$ & Wild Type \\
\hline erlotinib & 23 & 39 & 1600 & $>10000$ & 1020 \\
\hline afatinib & 0.2 & 0.2 & 141 & 196 & 31 \\
\hline rociletinib & 174 & 140 & 28 & 21 & 2052 \\
\hline osimertinib & 12 & 9 & 3 & 13 & 938 \\
\hline
\end{tabular}

B

\section{Selectivity index}

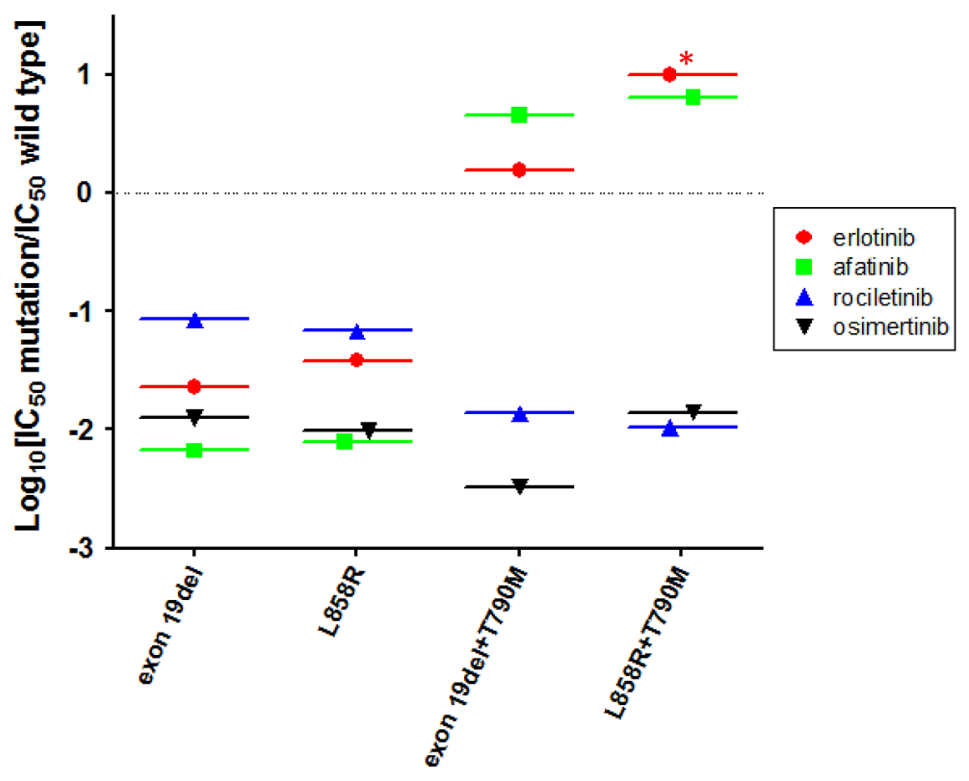

Figure 3: IC50 values and in vitro modeling. A. IC50 values (nM) of EGFR-TKIs for wild type and mutated EGFR are shown. Erlotinib, afatinib, osimertinib, and rociletinib were used as EGFR-TKIs. B. Calculated values of the selectivity index (SI) for EGFR mutations, exon 19 deletion, L858R, exon 19 deletion+T790M, and L858R+T790M. *; SI index >1.

indicating a wide therapeutic window of afatinib for these mutations. Interestingly, for $\mathrm{Ba} / \mathrm{F} 3$ cells harboring classic EGFR mutations, osimertinib showed mutation specificity similar to that of afatinib, and the SI values were around -2, indicating IC50 values for these classic mutations were about 100-fold lower than those for the wild-type EGFR.

For $\mathrm{Ba} / \mathrm{F} 3$ cells harboring EGFR T790M, $3^{\text {rd }}$ generation EGFR-TKIs, osimertinib and rociletinib, showed striking mutation specificity. The SI values were around -2 or lower, indicating IC50 values for T790M mutation more than 100-fold lower than those for the wild-type $E G F R$. Unfortunately, erlotinib and afatinib did not demonstrate mutation specificity for EGFR T790M mutations. The SI values were more than zero, indicating that the IC50 values of erlotinib and afatinib for EGFR T790M mutations were higher than those for the wild-type EGFR.
To determine and to confirm the clinical relevance of this in vitro model, we reviewed the data of human clinical trials. The efficacy of erlotinib for classic EGFR mutations $[41,42]$ and inefficacy of erlotinib for T790M mutations are reported [24] and well accepted. Our in vitro model clearly indicated the difference of erlotinib efficacy for classic EGFR mutations and its inefficacy for T790M mutations. Again, the efficacy of afatinib for classic EGFR mutations [43] and its inefficacy for T790M mutations are reported [36]. Data from our in vitro model were in agreement with these results. The efficacy of osimertinib and rociletinib for patients with NSCLC harboring EGFR T790M mutation and little dose limiting toxicities have recently been described. The striking mutation specificity of osimertinib and rociletinib shown in the model matches well with the results of the reported trials. In summary, the results of our in vitro model match well with the reported clinical trials. 
A
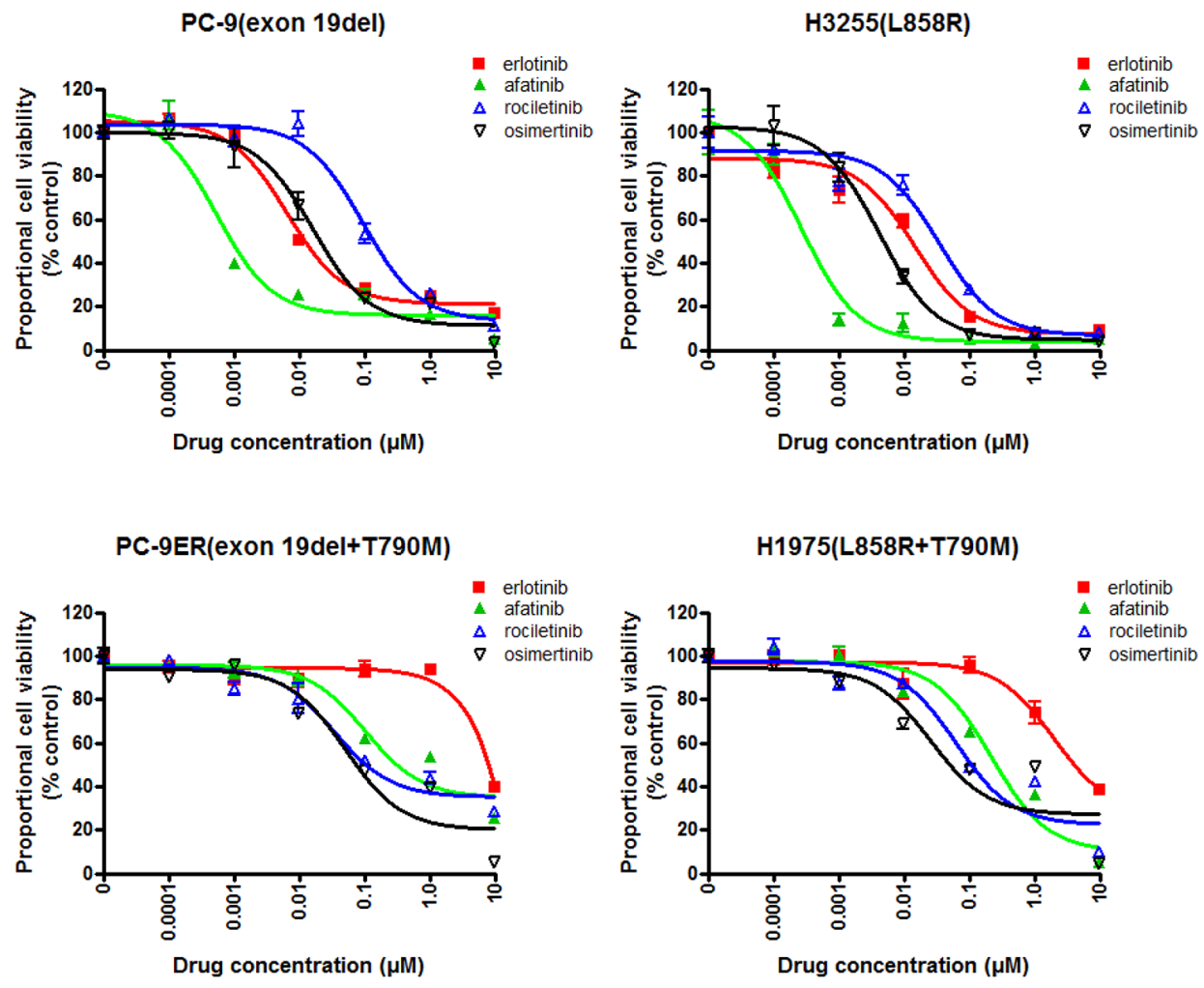

B

PC-9(exon 19del)

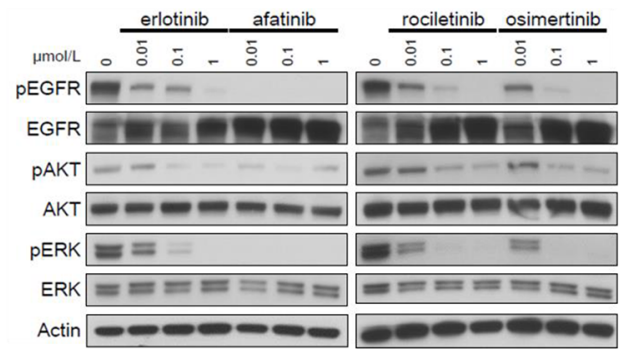

H3255(L858R)

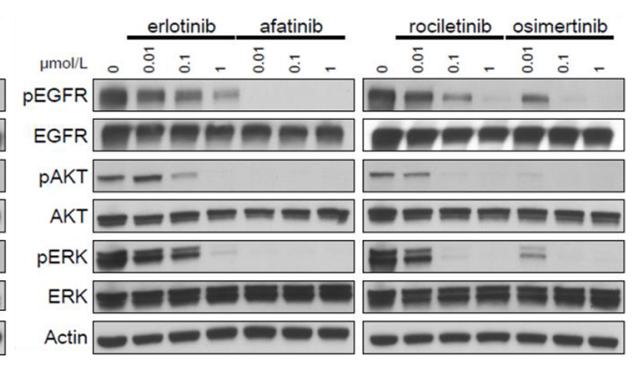

PC-9ER(exon 19del+T790M)

H1975(L858R+T790M)
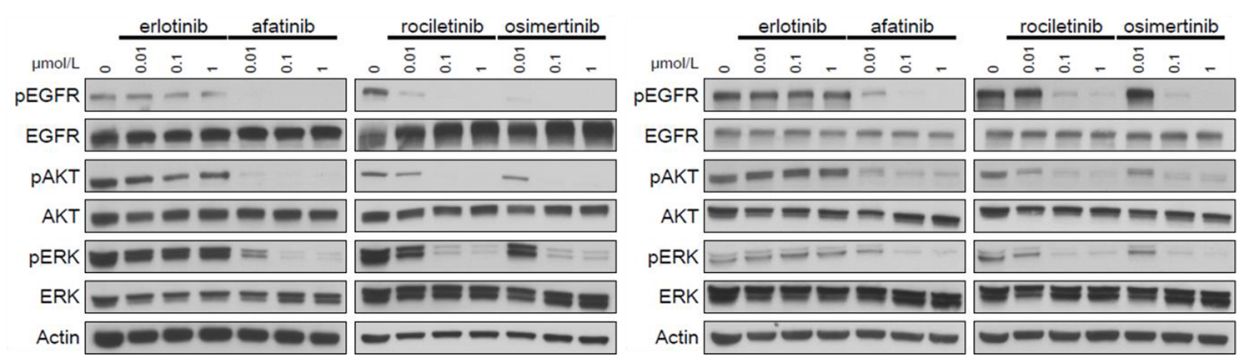

Figure 4: Sensitivity of lung cancer cell lines to EGFR-TKIs. A. MTS assay for PC-9, H3255, PC9-ER, and H1975 cells. The IC50 values (nM) for EGFR-TKIs are shown. Error bars indicate standard deviation. B. The results of immunoblotting for PC-9, H3255, PC9-ER, and H1975 cells are shown. The cells were treated with the indicated concentrations of EGFR-TKIs for $4 \mathrm{~h}$. Erlotinib, afatinib, osimertinib, and rociletinib were used as EGFR-TKIs. pEGFR, pAKT, and pERK indicate the phosphorylated form of EGFR, AKT, and ERK, respectively. Actin was used as a loading control. 


\section{Confirmation of the sensitivity/resistance profile of EGFR-TKIs in lung cancer cell lines}

Furthermore, to confirm that the sensitivity/ resistance profile data from $\mathrm{Ba} / \mathrm{F} 3$ stable cells are also observed in EGFR mutated human lung cancer derived cell lines, we performed MTS assay with or without EGFR-TKIs using human lung cancer derived cell lines (Figure 4A). The lung cancer cell lines used included PC-9 (EGFR exon 19del), H3255 (EGFR L858R), PC-9ER (EGFR exon 19 del+T790M), and H1975 (EGFR $\mathrm{L} 858 \mathrm{R}+\mathrm{T} 790 \mathrm{M})$.

The IC50 values of lung cancer cell lines are summarized in Table 1. For cell lines harboring classic EGFR mutations, exon 19 deletions (PC-9) and L858R (H3255), afatinib showed the most dramatic inhibitory effect. The calculated IC50 values of afatinib for PC-9 and $\mathrm{H} 3255$ were $0.8 \mathrm{nM}$ and $0.3 \mathrm{nM}$, respectively. Although less potent than afatinib, erlotinib effectively inhibited the proliferation of lung cancer cells as previously described [20]. The calculated IC50 values of erlotinib for PC-9 and $\mathrm{H} 3255$ were $7 \mathrm{nM}$ and $12 \mathrm{nM}$, respectively. The potency of osimertinib was comparable to that of erlotinib. However, rociletinib was less potent than erlotinib and osimertinib. The calculated IC50 values of osimertinib for PC-9 and $\mathrm{H} 3255$ were $17 \mathrm{nM}$ and $4 \mathrm{nM}$, respectively. The calculated IC50 values of rociletinib for PC-9 and H3255 were $84 \mathrm{nM}$ and $35 \mathrm{nM}$, respectively.

Erlotinib did not inhibit the proliferation of cell lines harboring EGFR T790M, PC-9ER and H1975, at low concentrations. However, afatinib and $3^{\text {rd }}$ generation EGFR-TKIs, osimertinib and rociletinib, effectively inhibited the proliferation of lung cancer cells. The calculated IC50 values of afatinib, osimertinib, and rociletinib for PC-9ER were $165 \mathrm{nM}, 13 \mathrm{nM}$, and $37 \mathrm{nM}$, respectively. The calculated IC50 values of afatinib, osimertinib, and rociletinib for $\mathrm{H} 1975$ were $57 \mathrm{nM}, 5 \mathrm{nM}$, and $23 \mathrm{nM}$, respectively. These data indicate that the sensitivity/resistance profile data observed in $\mathrm{Ba} / \mathrm{F} 3$ stable cells are similar to those observed in human lung cancer cell lines.

Furthermore, immunoblotting was performed to determine whether the aforementioned sensitivity of lung cancer cells to EGFR-TKIs was mediated through inhibition of the EGFR signaling pathway (Figure 4B).
Consistent with the results of the MTS assay, afatinib most potently inhibited the phosphorylation of EGFR and downstream proteins, AKT and ERK, in PC-9 and H3255 cells. Although less potent than afatinib, erlotinib and osimertinib effectively inhibited the phosphorylation of EGFR, AKT, and ERK in PC-9 and H3255. For the lung cancer cells harboring EGFR T790M, all EGFR-TKIs, but erlotinib, effectively inhibited the phosphorylation of EGFR, AKT, and ERK.

In summary, these data indicate that the sensitivity/ resistance profile observed in $\mathrm{Ba} / \mathrm{F} 3$ cells was confirmed in human lung cancer cells.

\section{Application of the in vitro model to EGFR exon 20 insertion mutations}

Except for EGFR A763_Y764insFQEA, most of EGFR exon 20 insertion mutations are reported to be resistant to $1^{\text {st }}$ generation EGFR-TKIs. Recently, the results of a clinical trial assessing afatinib treatment of patients with advanced NSCLC harboring uncommon EGFR mutations, including exon 20 insertion mutations have been reported [44]. Of the 23 NSCLC patients harboring EGFR exon 20 insertion mutations, only two (8.7\%) patients presented an objective response, indicating the limited efficacy of afatinib for exon 20 insertion mutations.

Until now, there is no EGFR-TKI reported to be effective against exon 20 insertion mutations. To examine the sensitivity/resistance profile of EGFR exon 20 insertion mutations to EGFR-TKIs, we performed MTS assays with or without EGFR-TKIs using cells harboring four representative $E G F R$ exon 20 insertion mutations, namely, A763_Y764insFQEA, Y764_V765insHH, A767_ V769dupASV, and D770_N771insNPG (Figure 5A). Afatinib potently inhibited the growth of cells harboring EGFR A763_Y764insFQEA. Of the other three EGFRTKIs, osimertinib most effectively inhibited $\mathrm{Ba} / \mathrm{F} 3$ cell growth.

Interestingly, for other $1^{\text {st }}$ generation EGFR-TKIs resistant $E G F R$ exon 20 insertion mutations, osimertinib and afatinib presented similar efficacy. The IC50 values of afatinib for Y764_V765insHH, A767_V769dupASV, and D770_N771 insNPG were 134, 158, and $43 \mathrm{nM}$,

Table 1: IC50 values (nM) of lung cancer cell lines

\begin{tabular}{|l|c|c|c|c|}
\hline \multicolumn{2}{c}{ erlotinib } & afatinib & rociletinib & osimertinib \\
\hline PC-9 (exon 19del) & 7 & 0.8 & 84 & 17 \\
\hline H3255 (L858R) & 12 & 0.3 & 35 & 4 \\
\hline PC-9ER (exon 19del+T790M) & $>10000$ & 165 & 37 & 13 \\
\hline H1975 (L858R+T790M) & 1185 & 57 & 23 & 5 \\
\hline BID007 (A763_Y764insFQEA) & 45 & 8 & 1278 & 40 \\
\hline
\end{tabular}


A
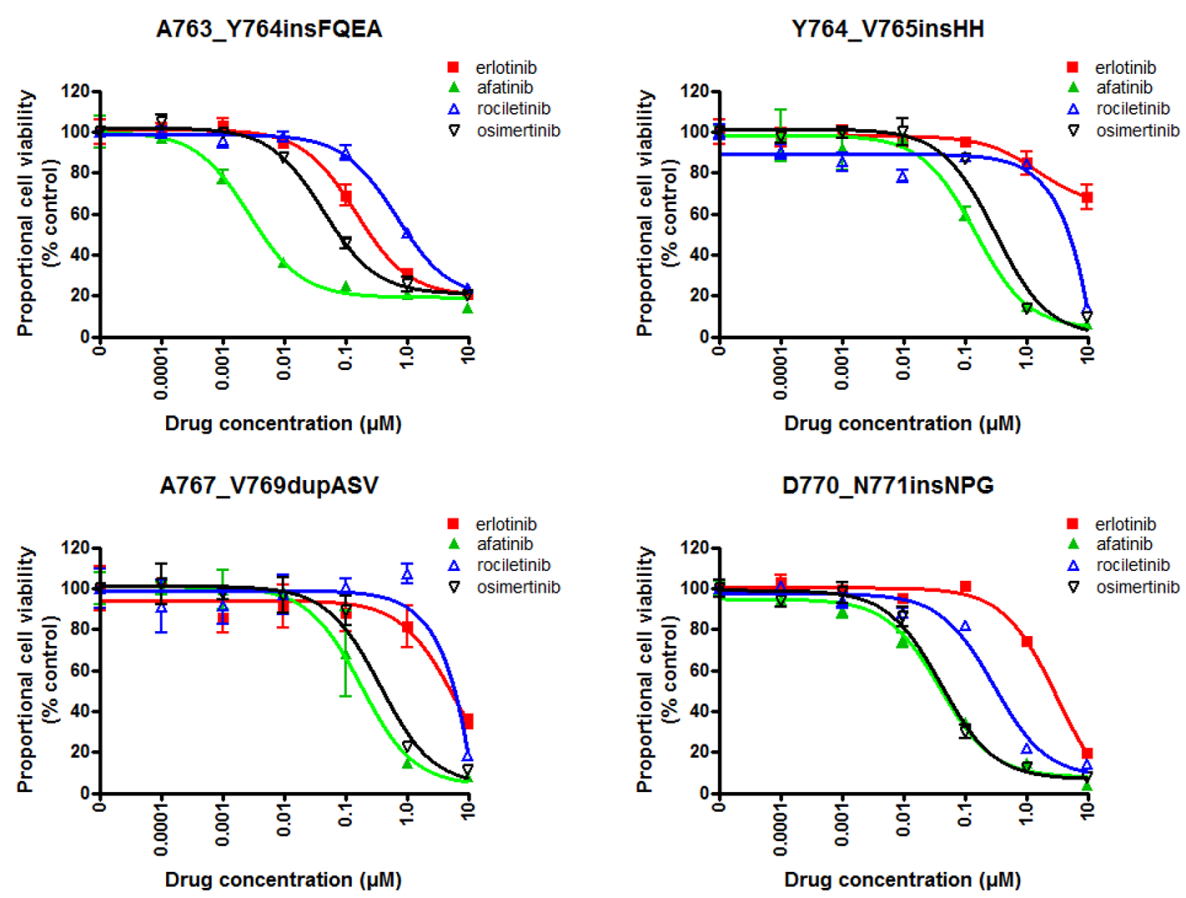

B

$\mathrm{IC}_{50}$ value $(\mathrm{nM})$

\begin{tabular}{|c|c|c|c|c|}
\hline & FQEA & $\mathrm{HH}$ & ASV & NPG \\
\hline erlotinib & 154 & $>10000$ & 1679 & 1146 \\
\hline afatinib & 3 & 134 & 158 & 43 \\
\hline rociletinib & 673 & 1730 & 5290 & 262 \\
\hline osimertinib & 44 & 237 & 333 & 42 \\
\hline
\end{tabular}

C

Selectivity index

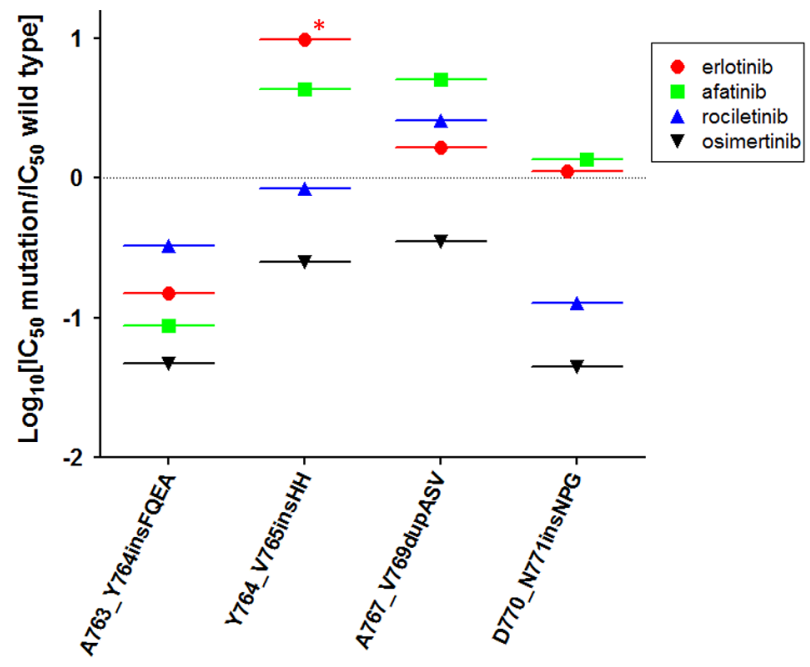

Figure 5: Sensitivity of Ba/F3 cells harboring EGFR exon 20 insertion mutations to EGFR-TKIs. A. MTS assay for $\mathrm{Ba} / \mathrm{F} 3$ cells harboring EGFR exon 20 insertion mutations. The mutations studied include A763_Y764insFQEA, Y764_V765insHH, A767_ V769dupASV, and D770_N771insNPG. The proportional cell viability is shown. Erlotinib, afatinib, osimertinib, and rociletinib were used as EGFR-TKIs. Error bars indicate standard deviation. B. IC50 values (nM) of EGFR-TKIs for EGFR exon 20 insertion mutations. C. The calculated values of the selectivity index (SI) for EGFR exon 20 insertion mutations are shown. *; SI index $>1$. 
respectively. The IC50 values of osimertinib for Y764_V765insHH, A767_V769dupASV, and D770 N771 insNPG were 237, 333, and $42 \mathrm{nM}$, respectively (Figure 5B).

To estimate the therapeutic window of EGFRTKIs for EGFR exon 20 insertion mutations, we applied the aforementioned in vitro model to exon 20 insertion mutations (Figure 5C). Surprisingly, we found that osimertinib presented the lowest SI values of around -1 , indicating IC50 values for EGFR exon 20 insertion mutations about 10 fold lower than those for the wild type EGFR. However, the SI values of other EGFR-TKIs were around or above zero. These data indicate that osimertinib may present a wide therapeutic window and is effective for several exon 20 insertion mutations.

\section{Biological confirmation of osimertinib efficacy for lung cancer harboring EGFR exon 20 insertion mutations}

To biologically confirm the aforementioned efficacy of osimertinib for lung cancer harboring EGFR exon 20 insertion mutations, further in vitro analyses were performed.

First, to confirm whether the above sensitivity pattern observed in $\mathrm{Ba} / \mathrm{F} 3$ cells was also observed in human lung cancer cell lines, we performed immunoblotting and MTS assays using BID007 (EGFR A763 Y764insFQEA) cells (Figure 6A). To our knowledge BID007 is the only cell line harboring EGFR exon 20 insertion mutations, which we originally established [20]. The sensitivity pattern and inhibition of the phosphorylation of EGFR and downstream proteins were consistent with the results observed in $\mathrm{Ba} / \mathrm{F} 3$ cells harboring EGFR A763_Y764insFQEA. The most dramatic inhibition of cell growth was observed with afatinib. The calculated IC50 value of afatinib for BID007 was $8 \mathrm{nM}$. Although less potent than afatinib, erlotinib and osimertinib effectively inhibited the proliferation of BID007 cells. The calculated IC50 value of erlotinib and osimertinib for BID007 was $45 \mathrm{nM}$ and $40 \mathrm{nM}$, respectively. However, rociletinib was less potent than erlotinib and osimertinib. The calculated IC50 value of rociletinib for BID007 was $1278 \mathrm{nM}$. These data indicate that the sensitivity pattern observed in $\mathrm{Ba} / \mathrm{F} 3$ cells was also observed in human lung cancer cell line, BID007.

Next, to confirm that the sensitivity of $\mathrm{Ba} / \mathrm{F} 3$ cells harboring $E G F R$ exon 20 insertion mutations was exerted through inhibition of the EGFR signaling pathway, we performed immunoblotting (Figure 6B). As expected, for EGFR A763_Y764insFQEA, afatinib dramatically inhibited the phosphorylation of EGFR, AKT, and ERK. Erlotinib and osimertinib similarly inhibited the phosphorylation of EGFR, AKT, and ERK. For other $1^{\text {st }}$ generation EGFR-TKIs resistant EGFR exon 20 insertion mutations, Y764_V765insHH, A767_V769dupASV and D770_N771insNPG, the inhibition of the phosphorylation of EGFR, AKT, and ERK was similar between osimertinib and afatinib.

Finally, to confirm the therapeutic window of osimertinib for $1^{\text {st }}$ generation EGFR-TKIs resistant EGFR exon 20 insertion mutations, we performed apoptosis assays using $\mathrm{Ba} / \mathrm{F} 3$ cells harboring wild type $E G F R$ and EGFR D770_N771insNPG. We stained the Ba/F3 cells with annexin V-APC and propidium iodide after $48 \mathrm{~h}$ of EGFR-TKI treatment $(0.1 \mu \mathrm{M})$. The proportion of annexin- $\mathrm{V}$ positive and/or propidium iodide positive cells was examined by flow cytometry (Figure 6C). As expected, afatinib induced apoptosis in both $\mathrm{Ba} /$ F3 cells harboring wild type EGFR and EGFR D770 N771insNPG, indicating a narrow therapeutic window of afatinib for EGFR D770_N771insNPG. The proportion of annexin- $\mathrm{V}$ positive cells was $82.5 \%$ for the wild type EGFR and $56.0 \%$ for EGFR D770_N771insNPG. In contrast, the effect of osimertinib on apoptosis in $\mathrm{Ba} / \mathrm{F} 3$ cells harboring wild type EGFR was low, while it was high in $\mathrm{Ba} / \mathrm{F} 3$ cells harboring EGFR D770 N771insNPG. The proportion of annexin- $\mathrm{V}$ positive cells was $29.1 \%$ for the wild type EGFR and $48.6 \%$ for EGFR D770 N771insNPG. These data indicate the wide therapeutic window of osimertinib for EGFR D770_N771insNPG.

In summary, we biologically confirmed the efficacy and therapeutic window of osimertinib for EGFR exon 20 insertion mutations.

\section{DISCUSSION}

In this study, we compared the potency of erlotinib, afatinib, osimertinib, and rociletinib against multiple types of EGFR mutations such as classic EGFR mutations, exon 19 deletions and L858R, with or without T790M, or exon 20 insertion mutations. Because EGFR is ubiquitously expressed in epithelial cells, EGFR-TKIs induce toxicity when EGFR-TKIs affect the wild type EGFR in epithelial cells. Hence, the therapeutic window, i.e., the difference in term of the concentrations that affect the wild type and mutated EGFR, is important. In this study, we created an in vitro model to determine the therapeutic window of EGFR-TKIs by calculating the ratio of IC50 values of EGFR-TKIs in cells stably expressing the wild type EGFR or the mutated EGFR.

In general, the data from $\mathrm{Ba} / \mathrm{F} 3$ stable cell lines and human lung cancer derived cell lines were consistent. For classic EGFR mutations, exon 19 deletions and L858R, afatinib was the most potent. Our data also showed a wide therapeutic window of afatinib for these mutations. However, in the clinic, the high frequency of adverse events such as skin rash or diarrhea is repeatedly reported $[34,35]$, indicating that the in vivo concentration of afatinib might exceed the concentration that inhibits the wild type EGFR. It is possible that, by reducing the dose, afatinib retains its ability to inhibit the mutated EGFR, but not the wild type EGFR. 
A
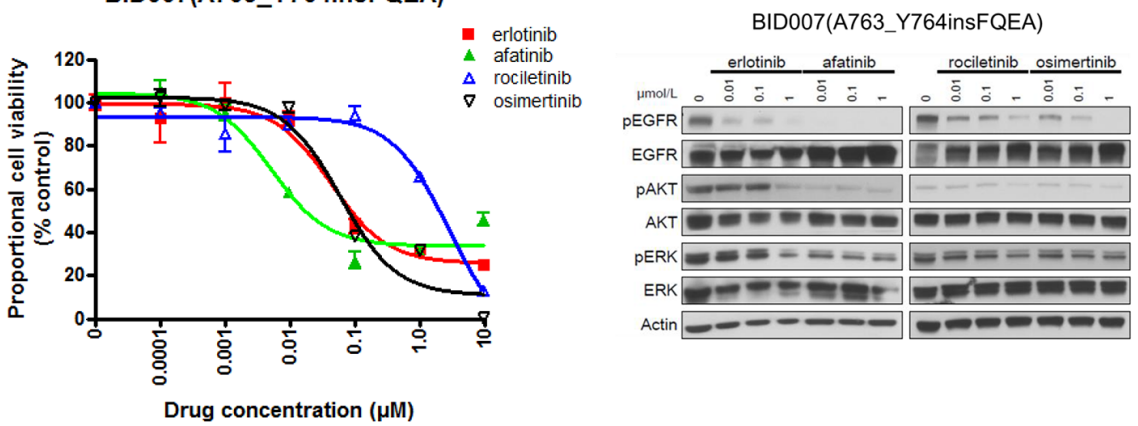

B

A763_Y764insFQEA

Y764_V765insHH
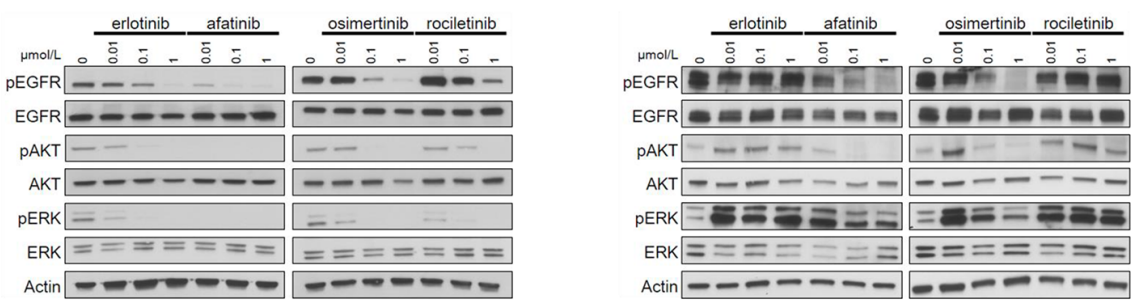

A767_V769dupASV

D770_N771insNPG
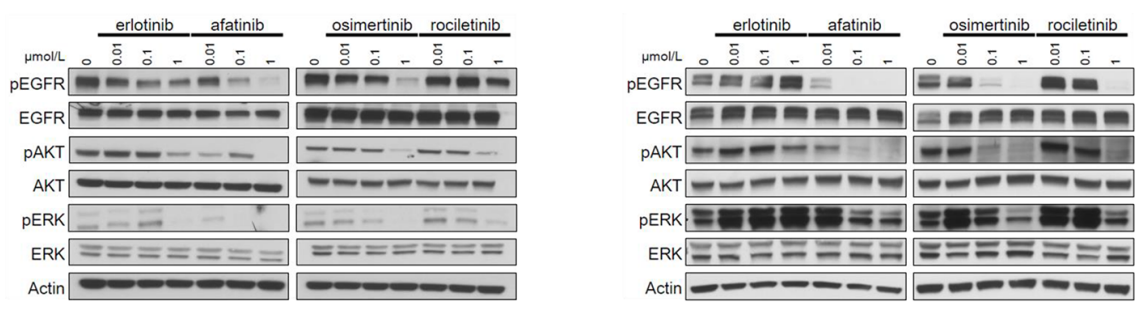

C

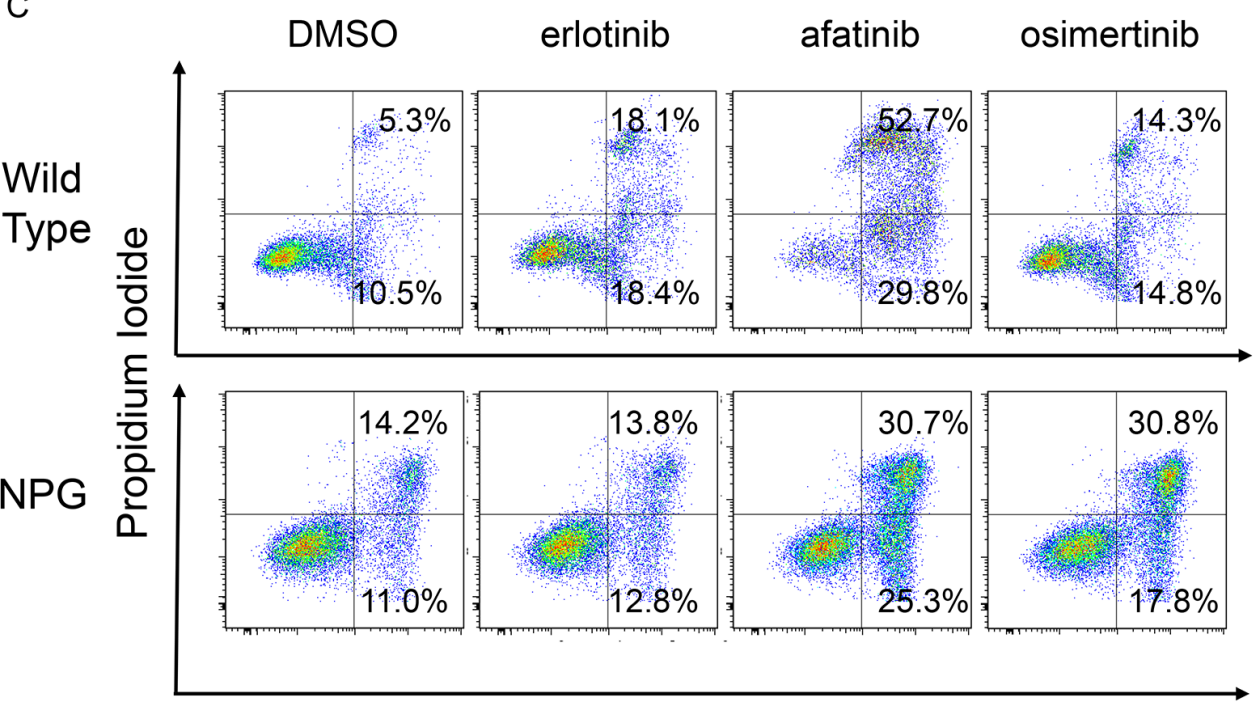

Annexin V-APC

Figure 6: Efficacy of EGFR-TKIs for EGFR exon 20 insertion mutations. A. MTS assay (left) and immunoblotting (right) for BID007 (EGFR A763_Y764insFQEA) cells. Error bars indicate standard deviation. B. Results of immunoblotting for Ba/F3 cells with EGFR exon 20 insertion mutations. The cells were treated with the indicated concentrations of EGFR-TKIs for $4 \mathrm{~h}$. Erlotinib, afatinib, osimertinib, and rociletinib were used as EGFR-TKIs. pEGFR, pAKT, and pERK indicate the phosphorylated form of EGFR, AKT, and ERK, respectively. Actin was used as a loading control. C. Apoptosis assay using cytometry. Ba/F3 cells harboring wild type EGFR and EGFR D770_N771insNPG (NPG) were treated with EGFR-TKIs for $48 \mathrm{~h}$, subsequently the cells were stained with propidium iodide and annexin $\mathrm{V}$-APC. The numbers indicate the proportion of annexin V-positive and/or propidium iodide-positive cells. 
For EGFR T790M positive mutations, osimertinib and rociletinib showed a strikingly potent inhibition compared to erlotinib or afatinib. In addition, osimertinib and rociletinib showed a wide therapeutic window for these mutations. These data indicate that osimertinib and rociletinib are effective and safe EGFR-TKIs for EGFR T790M positive mutations. In human clinical trials, osimertinib and rociletinib showed promising safety and efficacy, even though some hyperglycemia was observed in patients treated with rociletinib [38, 39].

Interestingly, for $1^{\text {st }}$ generation EGFR-TKIs resistant exon 20 insertion mutations, Y764_V765insHH, A767V769dupASV, and D770_N771 insNPG $\overline{\text {, osimertinib }}$ showed a similar potency and higher mutation specificity than afatinib. However, the IC50 values of osimertinib for these exon 20 insertion mutations are 10 to 100 fold higher than those for the classic EGFR mutations with or without T790M mutations. Thus, higher concentrations of osimertinib may be necessary to effectively treat the patients with $1^{\text {st }}$ generation EGFR-TKIs resistant exon 20 insertion mutations.

Preliminary pharmacokinetic profile, showing total plasma concentrations of osimertinib, was reported [30]. The mean plasma concentration of 6 patients treated with once-daily $20 \mathrm{mg}$ oral osimertinib dosing in the AURA phase I study (NCT01802632) was around $100 \mathrm{nM}$, which is around the IC50 values found in this study for $1^{\text {st }}$ generation EGFR-TKIs resistant exon 20 insertion mutations $(42-333 \mathrm{nM})$. In addition, the results of this phase I study have been reported [38]. The patients were assigned to once-daily dosing from $20 \mathrm{mg}$ to $240 \mathrm{mg}$. No dose-limiting toxicity was observed during the 28-day evaluation period at any dose levels. Therefore, a maximum tolerated dose was not determined. The maximum serum concentrations were 106.3, 305.1, 635.4, 1006 , and $1510 \mathrm{nM}$ for 20, 40, 80, 160, and $240 \mathrm{mg}$ dose levels, respectively. These data indicate that osimertinib concentration may be adjusted to the level that effectively inhibits the mutant EGFR, but not the wild type EGFR. To examine the efficacy of osimertinib for NSCLC harboring $1^{\text {st }}$ generation EGFR-TKIs resistant exon 20 insertion mutations, dose adjusted clinical trials are anticipated.

From the EGFR-TKIs oriented viewpoint, erlotinib is effective for EGFR exon 19 deletions, L858R, and A763_Y764insFQEA. However, erlotinib does not seem to be effective for EGFR T790M positive mutations as previously described [20]. Afatinib seems to be effective and has a wide therapeutic window for EGFR exon 19 deletion and L858R. However, afatinib was less potent than osimertinib and rociletinib for $E G F R$ T790M positive mutations. Osimertinib and rociletinib showed a potent efficacy and a wide therapeutic window for EGFR T790M positive mutations.

Even for $3^{\text {rd }}$ generation EGFR-TKIs, the potency spectrum was clearly different between osimertinib and rociletinib. Interestingly, for EGFR 19 deletion and
L858R, osimertinib efficacy was comparable with that of erlotinib, indicating that osimertinib can be used for EGFR 19 deletion and L858R as first line EGFR-TKI. Furthermore, we identified the therapeutic window of osimertinib for $1^{\text {st }}$ generation EGFR-TKIs resistant exon 20 insertion mutations. The reason why osimertinib showed a distinct wide mutation spectrum is unknown. However, it may be partly due to the distinct chemical structure of this compound [30]. To our knowledge, this is the first report, which clearly demonstrates the difference in term of mutation spectrum of EGFR-TKIs against various types of $E G F R$ mutations.

However, our study includes only in vitro study. The pharmacokinetics and pharmacodynamics may vary among EGFR-TKIs. Hence, EGFR-TKI in vivo concentrations may vary among EGFR-TKIs. To further develop a better strategy for using EGFR-TKIs, further in vivo and human clinical trials are mandatory.

In summary, we created an in vitro model to determine the therapeutic window of EGFR-TKIs, which matched well with the data obtained from human clinical trials. Interestingly, by applying the model, osimertinib showed the widest therapeutic window in relation to wild type EGFR for most mutations including EGFR exon 20 insertion mutations. This model will provide a preclinical rationale for proper selection of EGFR-TKIs against clinically-relevant EGFR mutations.

\section{MATERIALS AND METHODS}

\section{Cell lines}

Five human NSCLC cell lines were used, namely, PC-9 [EGFR exon 19 deletion (delE746-A750)], H3255 [EGFR L858R], PC-9ER [EGFR exon 19 deletion (delE746-A750)+T790M], BID007 [EGFR exon 20 insertion (A763_Y764insFQEA)], and H1975 [EGFR L858R+T790M]. PC9 cells were a kind gift from Dr. Pasi Janne (Dana-Farber Cancer Institute, Boston, MA, USA). H3255 and H1975 were purchased from the American Type Culture Collection (Manassas, VA, USA). PC-9ER cells become resistant to erlotinib after chronic exposure to erlotinib through acquisition of EGFR T790M second mutation. BID007 was originally established [20]. Cell authentication for H1975 and H3255 was performed in June 2015.

\section{Reagents}

Erlotinib and afatinib were purchased from LC Laboratories (Woburn, MA, USA). Osimertinib and rociletinib were purchased from Selleck Chemicals (Houston, TX, USA). Total EGFR antibody (\#2232), total AKT antibody (\#9272), phospho-AKT (S473; D9E) antibody (\#4060), total p44/42 MAPK antibody (\#9102S), and phospho-p44/42 MAPK (T202/204) antibody 
(\#9101S) were purchased from Cell Signaling Technology (Beverly, MA, USA). Phospho-EGFR (Y1068) antibody (44788G) was purchased from Invitrogen/Life Technologies (Carlsbad, CA, USA). Actin antibody was purchased from Sigma-Aldrich (St. Louis, MO, USA).

\section{Ba/F3 stable cell lines}

$\mathrm{Ba} / \mathrm{F} 3$ cells stably expressing the wild type and mutated $E G F R$ were created as previously described [20]. $\mathrm{Ba} / \mathrm{F} 3$ cells harboring $E G F R$ mutations were cultured in RPMI-1640 growth medium, supplemented with $10 \%$ fetal bovine serum at $37^{\circ} \mathrm{C}$ in a humidified $5 \% \mathrm{CO}_{2}$ incubator. $\mathrm{Ba} / \mathrm{F} 3$ cells expressing $E G F R$ wild type were cultured in RPMI-1640 growth medium, supplemented with 10\% fetal bovine serum at $37^{\circ} \mathrm{C}$ in a humidified $5 \% \mathrm{CO}_{2}$ incubator with EGF $(10 \mathrm{ng} / \mathrm{mL})$. The EGFR mutations examined in this study include delL747_P753insS (exon 19del), L858R, delL747 P753insS+T790M (exon 19del+T790M), L858R+T790M, A763_Y764insFQEA, Y764_V765insHH, A767_V769dupAS̄V, and D770 N771 insNPG.

\section{Cell proliferation assay}

The MTS assay was performed as previously described [20]. PC-9, H3255, PC-9ER, H1975, and BID007 were seeded in 96-well plates. Twenty-four hours after seeding, the appropriate medium with or without EGFR-TKI was added to each well. Control cells were treated with the same concentration of the vehicle, dimethyl sulfoxide (DMSO). Seventy-two hours after treatment, absorbance was measured.

For $\mathrm{Ba} / \mathrm{F} 3$ cells, the cells were seeded with or without EGFR-TKI. Seventy-two hours after seeding, absorbance was measured. All experiments were performed at least three times.

\section{Immunoblotting analysis}

Cells were treated with EGFR-TKI at concentrations of 0.01-1 $\mu \mathrm{mol} / \mathrm{L}$ for $4 \mathrm{~h}$. Cells were lysed in Cell Lysis Buffer (Cell Signaling Technology). Equal amounts of protein were loaded per lane on sodium dodecyl sulfatepolyacrylamide gels. Separated proteins were transferred to polyvinylidene fluoride membranes. The membranes were incubated overnight with primary antibodies at $4^{\circ} \mathrm{C}$ and then incubated with secondary antibodies for $1 \mathrm{~h}$. For the detection of proteins, the membranes were incubated with agitation in LumiGLO reagent and peroxide (Cell Signaling Technology) and then exposed to X-ray film.

\section{Apoptosis assay}

$\mathrm{Ba} / \mathrm{F} 3$ cells harboring wild type $E G F R$ and $E G F R$ D770_N771insNPG were seeded in 6-well plates. The cells were treated with EGFR-TKIs $(0.1 \mu \mathrm{M})$ for $48 \mathrm{~h}$.
Control cells were treated with the same concentration of the vehicle, DMSO. We analyzed the apoptotic status of cells using the Annexin V Apoptosis Detection Kit APC (eBioscience, San Diego, CA, USA) according to the manufacturer's protocol. The proportion of apoptotic cells was evaluated by flow cytometric analysis, using the Gallios flow cytometer system (Beckman Coulter, Brea, CA, USA).

\section{Statistical analysis}

Statistical analysis was performed using the GraphPad Prism software, version 4.0 (GraphPad Software, La Jolla, CA, USA). $\mathrm{IC}_{50}$ was calculated by using the GraphPad Prism software.

\section{ACKNOWLEDGMENTS}

We thank Ms. Mikiko Shibuya for her excellent technical assistance.

\section{CONFLICTS OF INTEREST}

D.B.C. has received consulting fees and honoraria from Pfizer Inc., Boehringer Ingelheim and Ariad Pharmaceuticals, respectively. D.B.C. also conducts unremunerated clinical trials using osimertinib (AstraZeneca) and rociletinib (Clovis Oncology).

\section{GRANT SUPPORT}

This work was supported in part by Grants-in-Aid for Scientific Research on Priority Areas from the Ministry of Education, Culture, Sports, Science, and Technology of Japan to K.S. (Grant \# 15K09229) and H.Y. (Grant \#25860656, 15H05666, 15K14398), National Institution of Health grants (R01CA169259 and R21CA17830) to S.S.K., American Cancer Society grant (RSG-13-047) to S.S.K., National University of Singapore-Beth Israel Deaconess Medical Center Joint Grant (NR12YLL203) to S.S.K., Lung Cancer Foundation of America-International Association for the Study of Lung Cancer grant to D.B.C., American Cancer Society grant (RSG-11-186) to D.B.C., and National Cancer Institute grants (CA090578) to D.B.C.

\section{REFERENCES}

1. Siegel R, Naishadham D, Jemal A. Cancer statistics, 2013. Ca-Cancer J Clin. 2013; 63:11-30.

2. Paez JG, Janne PA, Lee JC, Tracy S, Greulich H, Gabriel S, Herman P, Kaye FJ, Lindeman N, Boggon TJ, Naoki K, Sasaki H, Fujii Y, Eck MJ, Sellers WR, Johnson BE, et al. EGFR mutations in lung cancer: Correlation with clinical response to gefitinib therapy. Science. 2004; 304:1497-1500. 
3. Lynch TJ, Bell DW, Sordella R, Gurubhagavatula S, Okimoto RA, Brannigan BW, Harris PL, Haserlat SM, Supko JG, Haluska FG, Louis DN, Christiani DC, Settleman J, Haber DA. Activating mutations in the epidermal growth factor receptor underlying responsiveness of non-small-cell lung cancer to gefitinib. New Engl J Med. 2004; 350:2129-2139.

4. Kosaka T, Yatabe Y, Endoh H, Kuwano H, Takahashi T, Mitsudomi T. Mutations of the epidermal growth factor receptor gene in lung cancer: Biological and clinical implications. Cancer Res. 2004; 64:8919-8923.

5. Pao W, Miller V, Zakowski M, Doherty J, Politi K, Sarkaria I, Singh B, Heelan R, Rusch V, Fulton L, Mardis E, Kupfer D, Wilson R, Kris M, Varmus H. EGF receptor gene mutations are common in lung cancers from "never smokers" and are associated with sensitivity of tumors to gefitinib and erlotinib. P Natl Acad Sci USA. 2004; 101:13306-13311.

6. Shigematsu H, Lin L, Takahashi T, Nomura M, Suzuki M, Wistuba II, Fong KM, Lee H, Toyooka S, Shimizu N, Fujisawa T, Feng ZD, Roth JA, Herz J, Minna JD, Gazdar AF. Clinical and biological features associated with epidermal growth factor receptor gene mutations in lung cancers. J Natl Cancer I. 2005; 97:339-346.

7. Yun $\mathrm{CH}$, Boggon TJ, Li YQ, Woo MS, Greulich H, Meyerson M, Eck MJ. Structures of lung cancer-derived EGFR mutants and inhibitor complexes: Mechanism of activation and insights into differential inhibitor sensitivity. Cancer Cell. 2007; 11:217-227.

8. Jura N, Zhang XW, Endres NF, Seeliger MA, Schindler T, Kuriyan J. Catalytic Control in the EGF Receptor and Its Connection to General Kinase Regulatory Mechanisms. Mol Cell. 2011; 42:9-22.

9. Zhang XW, Gureasko J, Shen K, Cole PA, Kuriyan J. An allosteric mechanism for activation of the kinase domain of epidermal growth factor receptor. Cell. 2006; 125:1137-1149.

10. Sharma SV, Bell DW, Settleman J, Haber DA. Epidermal growth factor receptor mutations in lung cancer. Nat Rev Cancer. 2007; 7:169-181.

11. Nyati MK, Morgan MA, Feng FY, Lawrence TS. Integration of EGFR inhibitors with radiochemotherapy (vol 6, pg 876, 2006). Nat Rev Cancer. 2006; 6.

12. Costa DB, Halmos B, Kumar A, Schumer ST, Huberman MS, Boggon TJ, Tenen DG, Kobayashi S. BIM mediates EGFR tyrosine kinase inhibitor-induced apoptosis in lung cancers with oncogenic EGFR mutations. Plos Med. 2007; 4:1669-1680.

13. Rodgers K Network CGAR . Comprehensive molecular profiling of lung adenocarcinoma (vol 511, pg 543, 2014). Nature. 2014; 514.

14. Janne PA, Johnson BE. Effect of epidermal growth factor receptor tyrosine kinase domain mutations on the outcome of patients with non-small cell lung cancer treated with epidermal growth factor receptor tyrosine kinase inhibitors. Clin Cancer Res. 2006; 12:4416s-4420s.

15. Yasuda H, Kobayashi S, Costa DB. EGFR exon 20 insertion mutations in non-small-cell lung cancer: preclinical data and clinical implications (July 18, 2011). Lancet Oncol. 2011; 12:1182-1182.

16. Arcila ME, Nafa K, Chaft JE, Rekhtman N, Lau C, Reva BA, Zakowski MF, Kris MG, Ladanyi M. EGFR exon 20 insertion mutations in lung adenocarcinomas: prevalence, molecular heterogeneity, and clinicopathologic characteristics. Mol Cancer Ther. 2013; 12:220-229.

17. Mitsudomi T, Yatabe Y. Mutations of the epidermal growth factor receptor gene and related genes as determinants of epidermal growth factor receptor tyrosine kinase inhibitors sensitivity in lung cancer. Cancer Sci. 2007; 98:1817-1824.

18. Yuza Y, Glatt KA, Jiang J, Greulich H, Minami Y, Woo MS, Shimamura T, Shapiro G, Lee JC, Ji H, Feng W, Chen TH, Yanagisawa H, Wong KK, Meyerson M. Allele-dependent variation in the relative cellular potency of distinct EGFR inhibitors. Cancer Biol Ther. 2007; 6:661-667.

19. Greulich H, Chen TH, Feng W, Janne PA, Alvarez JV, Zappaterra M, Bulmer SE, Frank DA, Hahn WC, Sellers WR, Meyerson M. Oncogenic transformation by inhibitorsensitive and -resistant EGFR mutants. Plos Med. 2005; 2:e313.

20. Yasuda H, Park E, Yun CH, Sng NJ, Lucena-Araujo AR, Yeo WL, Huberman MS, Cohen DW, Nakayama S, Ishioka K, Yamaguchi N, Hanna M, Oxnard GR, Lathan CS, Moran T, Sequist LV, et al. Structural, Biochemical, and Clinical Characterization of Epidermal Growth Factor Receptor (EGFR) Exon 20 Insertion Mutations in Lung Cancer. Sci Transl Med. 2013; 5.

21. Oxnard GR, Lo PC, Nishino M, Dahlberg SE, Lindeman NI, Butaney M, Jackman DM, Johnson BE, Janne PA. Natural history and molecular characteristics of lung cancers harboring EGFR exon 20 insertions. J Thorac Oncol. 2013; 8:179-184.

22. Shepherd FA, Pereira JR, Ciuleanu T, Tan EH, Hirsh V, Thongprasert S, Campos D, Maoleekoonpiroj S, Smylie M, Martins R, van Kooten M, Dediu M, Findlay B, Tu DS, Johnston D, Bezjak A, et al. Erlotinib in previously treated non-small-cell lung cancer. New Engl J Med. 2005; 353:123-132.

23. Mok TS, Wu YL, Thongprasert S, Yang CH, Chu DT, Saijo N, Sunpaweravong $\mathrm{P}$, Han BH, Margono B, Ichinose $\mathrm{Y}$, Nishiwaki Y, Ohe Y, Yang JJ, Chewaskulyong B, Jiang HY, Duffield EL, et al. Gefitinib or Carboplatin-Paclitaxel in Pulmonary Adenocarcinoma. New Engl J Med. 2009; 361:947-957.

24. Kobayashi S, Boggon TJ, Dayaram T, Janne PA, Kocher O, Meyerson M, Johnson BE, Eck MJ, Tenen DG, Halmos B. EGFR mutation and resistance of non-small-cell lung cancer to gefitinib. New Engl J Med. 2005; 352:786-792. 
25. Pao W, Miller VA, Politi KA, Riely GJ, Somwar R, Zakowski MF, Kris MG, Varmus H. Acquired resistance of lung adenocarcinomas to gefitinib or erlotinib is associated with a second mutation in the EGFR kinase domain. Plos Med. 2005; 2:225-235.

26. Li D, Ambrogio L, Shimamura T, Kubo S, Takahashi M, Chirieac LR, Padera RF, Shapiro GI, Baum A, Himmelsbach F, Rettig WJ, Meyerson M, Solca F, Greulich H, Wong KK. BIBW2992, an irreversible EGFR/ HER2 inhibitor highly effective in preclinical lung cancer models. Oncogene. 2008; 27:4702-4711.

27. Engelman JA, Zejnullahu K, Gale CM, Lifshits E, Gonzales AJ, Shimamura T, Zhao F, Vincent PW, Naumov GN, Bradner JE, Althaus IW, Gandhi L, Shapiro GI, Nelson JM, Heymach JV, Meyerson M, et al. PF00299804, an irreversible pan-ERBB inhibitor, is effective in lung cancer models with EGFR and ERBB2 mutations that are resistant to gefitinib. Cancer Res. 2007; 67:11924-11932.

28. Gonzales AJ, Hook KE, Althaus IW, Ellis PA, Trachet E, Delaney AM, Harvey PJ, Ellis TA, Amato DM, Nelson JM, Fry DW, Zhu T, Loi CM, Fakhoury SA, Schlosser KM, Sexton KE, et al. Antitumor activity and pharmacokinetic properties of PF-00299804, a second-generation irreversible pan-erbB receptor tyrosine kinase inhibitor. Mol Cancer Ther. 2008; 7:1880-1889.

29. Zhou WJ, Ercan D, Chen L, Yun CH, Li DN, Capelletti M, Cortot AB, Chirieac L, Iacob RE, Padera R, Engen JR, Wong KK, Eck MJ, Gray NS, Janne PA. Novel mutantselective EGFR kinase inhibitors against EGFR T790M. Nature. 2009; 462:1070-1074.

30. Cross DAE, Ashton SE, Ghiorghiu S, Eberlein C, Nebhan CA, Spitzler PJ, Orme JP, Finlay MRV, Ward RA, Mellor MJ, Hughes G, Rahi A, Jacobs VN, Brewer MR, Ichihara E, Sun J, et al. AZD9291, an Irreversible EGFR, TKI, Overcomes T790M-Mediated Resistance to EGFR Inhibitors in Lung Cancer. Cancer Discov. 2014; 4:1046-1061.

31. Finlay MRV, Anderton M, Ashton S, Ballard P, Bethel PA, Box MR, Bradbury RH, Brown SJ, Butterworth S, Campbell A, Chorley C, Colclough N, Cross DAE, Currie GS, Grist M, Hassall L, et al. Discovery of a Potent and Selective EGFR Inhibitor (AZD9291) of Both Sensitizing and T790M Resistance Mutations That Spares the Wild Type Form of the Receptor. J Med Chem. 2014; 57 : 8249-8267.

32. Walter AO, Sjin RTT, Haringsma HJ, Ohashi K, Sun J, Lee K, Dubrovskiy A, Labenski M, Zhu ZD, Wang ZG, Sheets M, St Martin T, Karp R, van Kalken D, Chaturvedi P, Niu DQ, et al. Discovery of a Mutant-Selective Covalent Inhibitor of EGFR that Overcomes T790M-Mediated Resistance in NSCLC. Cancer Discov. 2013; 3:1404-1415.

33. Sjin RTT, Lee K, Walter AO, Dubrovskiy A, Sheets M, St Martin T, Labenski MT, Zhu ZD, Tester R, Karp R,
Medikonda A, Chaturvedi P, Ren YX, Haringsma H, Etter J, Raponi $\mathrm{M}$, et al. In Vitro and In Vivo Characterization of Irreversible Mutant-Selective EGFR Inhibitors That Are Wild-Type Sparing. Mol Cancer Ther. 2014; 13: 1468-1479.

34. Sequist LV, Yang JCH, Yamamoto N, O'Byrne K, Hirsh V, Mok T, Geater SL, Orlov S, Tsai CM, Boyer M, Su WC, Bennouna J, Kato T, Gorbunova V, Lee KH, Shah R, et al. Phase III Study of Afatinib or Cisplatin Plus Pemetrexed in Patients With Metastatic Lung Adenocarcinoma With EGFR Mutations. J Clin Oncol. 2013; 31:3327.

35. Wu YL, Zhou CC, Hu CP, Feng JF, Lu S, Huang YC, Li W, Hou M, Shi JH, Lee KY, Xu CR, Massey D, Kim M, Shi Y, Geater SL. Afatinib versus cisplatin plus gemcitabine for first-line treatment of Asian patients with advanced nonsmall-cell lung cancer harbouring EGFR mutations (LUXLung 6): an open-label, randomised phase 3 trial. Lancet Oncol. 2014; 15:213-222.

36. Katakami N, Atagi S, Goto K, Hida T, Horai T, Inoue A, Ichinose Y, Koboyashi K, Takeda K, Kiura K, Nishio K, Seki Y, Ebisawa R, Shahidi M, Yamamoto N. LUX-Lung 4: a phase II trial of afatinib in patients with advanced non-small-cell lung cancer who progressed during prior treatment with erlotinib, gefitinib, or both. J Clin Oncol. 2013; 31:3335-3341.

37. Miller VA, Hirsh V, Cadranel J, Chen YM, Park K, Kim SW, Zhou C, Su WC, Wang M, Sun Y, Heo DS, Crino L, Tan EH, Chao TY, Shahidi M, Cong XJ, et al. Afatinib versus placebo for patients with advanced, metastatic nonsmall-cell lung cancer after failure of erlotinib, gefitinib, or both, and one or two lines of chemotherapy (LUX-Lung 1): a phase 2b/3 randomised trial. Lancet Oncol. 2012; 13:528-538.

38. Janne PA, Yang JCH, Kim DW, Planchard D, Ohe Y, Ramalingam SS, Ahn MJ, Kim SW, Su WC, Horn L, Haggstrom D, Felip E, Kim JH, Frewer P, Cantarini M, Brown KH, et al. AZD9291 in EGFR Inhibitor-Resistant Non-Small-Cell Lung Cancer. New Engl J Med. 2015; 372:1689-1699.

39. Sequist LV, Soria JC, Goldman JW, Wakelee HA, Gadgeel SM, Varga A, Papadimitrakopoulou V, Solomon BJ, Oxnard GR, Dziadziuszko R, Aisner DL, Doebele RC, Galasso C, Garon EB, Heist RS, Logan J, et al. Rociletinib in EGFR-Mutated Non-Small-Cell Lung Cancer. New Engl J Med. 2015; 372:1700-1709.

40. Eskens FA, Mom CH, Planting AS, Gietema JA, Amelsberg A, Huisman H, van Doorn L, Burger H, Stopfer P, Verweij J, de Vries EG. A phase I dose escalation study of BIBW 2992, an irreversible dual inhibitor of epidermal growth factor receptor 1 (EGFR) and 2 (HER2) tyrosine kinase in a 2-week on, 2-week off schedule in patients with advanced solid tumours. Br J Cancer. 2008; 98:80-85.

41. Rosell R, Carcereny E, Gervais R, Vergnenegre A, Massuti B, Felip E, Palmero R, Garcia-Gomez R, Pallares C, Sanchez JM, 
Porta R, Cobo M, Garrido P, Longo F, Moran T, Insa A, et al. Erlotinib versus standard chemotherapy as first-line treatment for European patients with advanced EGFR mutation-positive non-small-cell lung cancer (EURTAC): a multicentre, open-label, randomised phase 3 trial. Lancet Oncol. 2012; 13:239-246.

42. Shepherd FA, Rodrigues Pereira J, Ciuleanu T, Tan EH, Hirsh V, Thongprasert S, Campos D, Maoleekoonpiroj S, Smylie M, Martins R, van Kooten M, Dediu M, Findlay B, Tu D, Johnston D, Bezjak A, et al. Erlotinib in previously treated non-small-cell lung cancer. N Engl J Med. 2005; 353:123-132.

43. Yang JC, Wu YL, Schuler M, Sebastian M, Popat S, Yamamoto N, Zhou C, Hu CP, O’Byrne K, Feng J, Lu S,
Huang Y, Geater SL, Lee KY, Tsai CM, Gorbunova V, et al. Afatinib versus cisplatin-based chemotherapy for EGFR mutation-positive lung adenocarcinoma (LUXLung 3 and LUX-Lung 6): analysis of overall survival data from two randomised, phase 3 trials. Lancet Oncol. 2015; 16:141-151.

44. Yang JC, Sequist LV, Geater SL, Tsai CM, Mok TS, Schuler M, Yamamoto N, Yu CJ, Ou SH, Zhou C, Massey D, Zazulina V, Wu YL. Clinical activity of afatinib in patients with advanced non-small-cell lung cancer harbouring uncommon EGFR mutations: a combined post-hoc analysis of LUX-Lung 2, LUX-Lung 3, and LUX-Lung 6. Lancet Oncol. 2015. 